\title{
The Use of Seesaw in Increasing Pupils' Reading Interest
}

\author{
Lee Yi Rou, Melor Md Yunus*
}

Faculty of Education, Universiti Kebangsaan Malaysia, Malaysia

Received March 8, 2020; Revised April 17, 2020; Accepted May 3, 2020

Copyright $\mathrm{C} 2020$ by authors, all rights reserved. Authors agree that this article remains permanently open access under the terms of the Creative Commons Attribution License 4.0 International License

\begin{abstract}
Good reading skills enable understanding of a piece of writing. According to Malaysian Curriculum Development Department [31], reading skill is one of the focus language skills. However, pupils are showing least interest in reading particularly English materials. This paper aimed to examine the effectiveness of using Seesaw, an online application, to increase the interest of reading for Year 3(9-year-old) ESL pupils in a school in Selangor. Seesaw is a digital portfolio that empowers pupils by providing them with a platform to showcase their learning in school. With Seesaw, pupils could learn from the feedback of their peers and teacher regardless of the time frame and geographical factors. This virtual platform has gained pupils' motivation to present on a reading task and aroused their interest in accomplishing reading tasks. This research is only focused on the effectiveness of using Seesaw to increase the interest of pupils in reading in Seri Kembangan, Selangor area. The data were collected from interviews and questionnaires with the adaptation of action research model by Kemmis and McTaggart. A total of 30 Year 3 pupils who are studying in the same school were purposively selected as the sampling of the study. Results have shown that the interest of pupils in reading is increased after using Seesaw. Hence, further study is needed to ascertain the effectiveness of using Seesaw in other language skills. Future studies with more participants from different levels are also needed to generalise the findings to a larger population and provide a deeper insight.
\end{abstract}

Keywords Reading Interest, Seesaw, ESL Learners

\section{Introduction}

In recent years, there has been an increased focus on reading skills among primary pupils. This can be seen when countries around the world participated in international reading tests. The Progress in International Reading Literacy Study (PIRLS) in 2018 [1], an international reading assessment participated by fifty countries around the world, shown more than half of the PIRLS 2016 countries (almost 95 percent of the students) demonstrated fundamental reading skills. One of the key findings from the results was good readers had positive attitudes toward reading and this can lead to better development of reading comprehension skills and strategies. These findings showed the importance of reading in developing literacy skills and improving the proficiency of the language.

However, learners who showed less interest in reading is regarded as one of the ESL classroom issues. It had raised concerns among educators, academics and education officers to urgently call for strategies to cultivate reading habits and interests among Malaysian students [2]. Pupils are showing least interest in reading due to limited classroom language opportunity, low immersive language environment and negligence of extensive reading out of the classroom [3]. Besides, the researchers also noticed that pupils in their school have a higher tendency in reading books in pupils' native language than to read in English.

Apart from that, the researchers also often encounter problems when communications with parents take place. Most of the time, parents are unaware of their children's performance in school until they were contacted because of the misbehaviour or learning problems faced by their children in school. Consequently, the performance of the pupils in school contradicted with the perceptions of their parents towards them, leading shocking parents.

To alleviate this problem, Seesaw, a digital platform that enabled pupils to demonstrate and share their reading experience, is employed in this study to increase pupils' reading interest. This is in line with a study by Yunus, et al. [4], suggested that ICT can be used as a useful tool to enhance the learning process. This collaborative platform not only allowed pupils to share experience, exchange ideas or give compliments to their peers' work but also aroused their interest in the task assigned. It compiled pupils' work as a digital portfolio for teachers to evaluate pupils' reading skill and give feedback correspondingly for pupils to revise their reading tasks. Furthermore, it also provided a platform to keep parents on the loop and allow parents to play a part by showing acknowledgement in 
children's reading tasks. Hence, this study aimed to explore the effectiveness of Seesaw in increasing the pupils' reading interest in ESL classroom.

\section{Literature Review}

\subsection{Seesaw}

Seesaw, a digital platform, empowers pupils to demonstrate and share learning, unlock creative thinking for all students in any subjects, gain insights for teachers to acquaint themselves to the strength and growth of the pupils and last but not least, engage families in conversations-centered on students' learning [5]. It is a free application which enables pupils to capture and present their work in a digital portfolio, eases teachers' job in monitoring pupils' progression and allows parents to leave constructive comments and feedback on pupils' work. It also works as a shared platform where pupils could work collaboratively with their peers by giving reflective comments to their friends. According to Yunus, et al. [6], the integration of ICT in teaching was said to encourage learners' independence and self-discovery skills. Furthermore, this online application also works as a tool which makes learning more flexible despite time and geographical factors [7]. Hence, this is indeed a useful approach to promote self-improvement among pupils.

Other than improving the pupils' performance and interest, Seesaw, the digital portfolio also promotes teachers' reflection and growth. Melland and Volden [8] described portfolios as an approach to document teaching effectiveness based on materials chosen, presented and organized by the teacher. This is coherent with what suggested by Murray [9], that a portfolio is useful in promoting professional development among teachers and it inspires and directs personal renewal and growth, allowing teachers to review, keep and track on their personal development in their teaching and learning.

In a nutshell, Seesaw, the online platform, obtains great potential in promoting teaching and learning for both pupils and teachers. Therefore, it is chosen as the intervention in this study to arouse the interest of pupils in the reading classroom.

\subsection{Importance of Interest in Reading}

Interest is relatively interacting between certain aspects of an individual's environment and the individual himself and is, therefore, content specific [10]. Interest is seen as containing two components, namely the cognitive and the affective component of the individual. It is known as an affective component where it causes an influential effect on cognitive functioning and determines the academic performance of the individual. A study shows both interest and effort are oppositional and complementary [11]. For instance, pupils who find a particular task interesting tend to complete it in a shorter period compared to those who have less interest and motivation in the same task. In other words, with sufficient interest, pupils are more likely to establish a better understanding in learning [12], and in this case, reading skills.

One of the goals in teaching reading is to develop the desire to read in children so they will become life-long readers [13]. Meanwhile, Coan [14] stated situational interest focuses on the environment and contextual factors. In reading classrooms, teachers play a crucial role in providing time for pupils to enjoy and appreciate good reading materials and increase their exposure to literature. Teachers are also presumed to seize for the pupils' attention and stimulate their curiosity to promote their interest. Studies have shown the interest of pupils is the primary influence of learning. Similarly, it can transform the low achievers to high performers. Hence, to develop efficient and self-motivated readers, teachers should have appropriate approaches and methods to encourage pupils to read more in school and at home, and create more enjoyable reading experiences in order to cultivate interest in reading.

\subsection{Previous Studies Related to Reading Classroom}

Reading is one of the most important elements in literacy development as it opens up knowledge opportunities and provides enjoyment. However, in parallel with changes in society, economy and culture, the concept of reading and reading literacy have been revised. It no longer particularly refers to an ability to be acquired in school. Instead, the new concept of learning has transformed into a practice of lifelong learning, including reading literacy.

Reading literacy is also viewed as an expanding set of knowledge, skills and strategies that individuals build on throughout life in various contexts, through interaction with their peers and the wider community [15]. In other words, learning to read is learning to use the language to comprehend a written text. However, not all reading experiences may be pleasurable for ESL readers as they might face difficulties in understanding a text [16]. To understand a text, readers need knowledge of morphology, phonology, syntax and lexicology, to comprehend the overall idea of the text and its components as a systemic, functional language [17]. In the long run, reading results in a knowledgeable future generation that spurs the country towards an era of globalization [18].

With the policy of 21 st century learning, there has been a keen interest in using technologies in education, and in getting knowledge on how they would affect the educational outcome of classrooms and learners [19]. It is also believed that teaching-learning process can be enhanced where learners are attracted by the mobility, accessibility and privacy in educational technologies [20]. In Malaysia, concerns were raised over low literacy attainment in English language among Malaysia learners. According to a survey conducted by Malaysia National 
Library in 2005 [21], an average Malaysian only reads approximately two books in a year. This shocking fact has alarmed the country and identified as one of the factors for low literacy among Malaysians, including their competency in English, which these two are closely related.

To elucidate this problem, measures were taken by the Ministry of Education through the launching of Malaysia Education Blueprint 2013-2025 [22], where it highlights on the achievement for $100 \%$ basic bilingual (Bahasa Malaysia and English Language) literacy proficiency after three years of formal schooling among learners. Hence, apart from making the pupils autonomous learners, the study aims to arouse pupils' interest and motivation in the reading classroom.

\section{Research Methodology}

This study adopted the action research model designed by Stephen Kemmis and McTaggart. This framework consists of four stages which are planning, action and observation and reflection. Later, the effectiveness of the cycle was evaluated and the plan was revised in order to carry on the second cycle.

Firstly, the researchers identified the existing problem in this study which is the low achievement in reading skill among 9-year-old primary school pupils. Purposive sampling method was employed in this research as it allowed the researcher to select a specific group that will be able to provide data and relevant information for the research [23]. In order to study the effectiveness of Seesaw in arousing the reading interest among the Year 3 ESL pupils in a primary school in Selangor, the researchers conducted a survey of the book-reading frequency among 9 -year-old pupils in a week. Later, thirty pupils with low reading frequency ( $0-3$ books in a week) and low reading performance (who are able to read short simple texts with a lot of support from the teacher) were selected as the respondents of this study.

Next, in the action and observe stage, the researchers carried out the reading activity and the recordings of the activities were uploaded in Seesaw. Through this tool, pupils' recordings were viewed by themselves, their peers and parents. Parents were acknowledged on the update of their child's task and comments were required. Meanwhile, respondents were asked to view their peers' reading tasks and constructive comments were highly encouraged as their feedback. Respondents were also allowed to upload more reading tasks after reflecting themselves based on the comments given by their teacher, peers and parents.

The data was collected in stage three. Questionnaire and interviews were conducted before and after the action and observation stage and later analyzed by the researchers. A 12-item questionnaire was adopted to identify pupils' attitude in reading. Before the collection of data, the questionnaire was piloted by two experts in the field. Also, to ensure the questions are comprehensive without any ambiguity among the 9 year-old respondents, the questionnaire was administered with the guidance of a teacher to provide a further explanation when the respondents faced vocabulary comprehension challenges and other hiccups. To obtain detailed information of the respondents' perception, an interview which consists of 5 questions was conducted and later transcribed to support and further explain the data collected throughout the study. In the final stage, reflection was done by the researchers on the efficacy of using Seesaw to increase the interest of reading among the students

To carry out the survey, the researchers employed a quantitative approach to collect data using a questionnaire. This survey consisted of two sections. The first section solicited demographic information of the respondents while the second section is to know their attitude towards reading with the choice of "Yes", "Not sure" and "No". To analyse the data collected, percentages were employed to present the perceptions of respondents towards reading and the factors affecting their reading attitude.

\section{Findings and Discussion}

In the findings and discussion part, the researchers analyzed the data collected from the survey of the students and the data are presented in table form.

Table 1. Demographic Profile of Respondents

\begin{tabular}{|c|c|c|}
\hline \multirow{2}{*}{ Gender } & Male & 17 \\
\cline { 2 - 3 } & Female & 13 \\
\hline \multirow{4}{*}{ Duration of Reading English Materials } & $1-3$ years & 5 \\
\cline { 2 - 3 } & $4-6$ years & 19 \\
\cline { 2 - 3 } & $7-9$ years & 6 \\
\hline
\end{tabular}

In this study, there are 17 male respondents and 13 female respondents. However, there is no gender comparison in this study and hence, no quota was set for each gender. Meanwhile, the duration of reading English materials of all the respondents are tabulated in Table 1. Only 6 of the respondents started reading English materials when they were 0 to 2 years old while 19 of them were exposed to English reading materials since 3 years old. Also, there are 5 of them only started to read English materials since they were 7 years old. This indicates that most of them (from 3 to 9 years old) only exposed to English reading materials when they started pre-school and primary education while studies shown literacy development that started early has a high correlation with school achievement [24]. Through the early exposure of English reading materials, children are believed to have better achievement in the language. 
Table 2. Attitudes to Reading (Pre and Post Activity)

\begin{tabular}{|c|l|c|c|c|c|c|c|}
\hline \multirow{2}{*}{} & \multicolumn{2}{|c|}{ Item } & \multicolumn{3}{|c|}{ (Pre- Implementation) } & \multicolumn{3}{c|}{ (Post- Implementation) } \\
\cline { 3 - 8 } & \multicolumn{1}{|c}{ Yes } & Not sure & No & Yes & Not sure & No \\
\hline 1 & I like reading stories. & $68 \%$ & $25 \%$ & $7 \%$ & $84 \%$ & $14 \%$ & $2 \%$ \\
\hline 2 & I do not like reading books. & $58 \%$ & $24 \%$ & $18 \%$ & $48 \%$ & $14 \%$ & $38 \%$ \\
\hline 3 & $\begin{array}{l}\text { I like reading comics or } \\
\text { magazines. }\end{array}$ & $40 \%$ & $6 \%$ & $54 \%$ & $43 \%$ & $6 \%$ & $51 \%$ \\
\hline 4 & I think reading is difficult. & $74 \%$ & $0 \%$ & $26 \%$ & $52 \%$ & $0 \%$ & $48 \%$ \\
\hline 5 & $\begin{array}{l}\text { I like watching TV better than } \\
\text { reading books. }\end{array}$ & $68 \%$ & $2 \%$ & $30 \%$ & $66 \%$ & $0 \%$ & $34 \%$ \\
\hline 6 & I like going to the library. & $52 \%$ & $5 \%$ & $43 \%$ & $79 \%$ & $1 \%$ & $20 \%$ \\
\hline 7 & $\begin{array}{l}\text { I have a lot of books to read at } \\
\text { home. }\end{array}$ & $56 \%$ & $5 \%$ & $39 \%$ & $61 \%$ & $1 \%$ & $38 \%$ \\
\hline 8 & $\begin{array}{l}\text { I like to have my teacher or } \\
\text { parents to read with me. }\end{array}$ & $89 \%$ & $3 \%$ & $8 \%$ & $91 \%$ & $2 \%$ & $7 \%$ \\
\hline 9 & I think reading is fun. & $31 \%$ & $0 \%$ & $69 \%$ & $61 \%$ & $0 \%$ & $39 \%$ \\
\hline 10 & I like reading with friends. & $64 \%$ & $6 \%$ & $30 \%$ & $79 \%$ & $2 \%$ & $19 \%$ \\
\hline 11 & I like reading alone. & $44 \%$ & $10 \%$ & $46 \%$ & $43 \%$ & $1 \%$ & $56 \%$ \\
\hline 12 & I think reading is boring. & $69 \%$ & $0 \%$ & $31 \%$ & $41 \%$ & $0 \%$ & $59 \%$ \\
\hline
\end{tabular}

In Table 2, the findings have shown the attitudes of respondents to reading before and after Seesaw activities. Before the activity, pupils are found having less interest in reading books. There are only $68 \%$ of them like reading stories while $58 \%$ of them do not like reading books. At the same time, $74 \%$ think that reading is difficult for them and $69 \%$ think reading is a boring activity. During the pre-activity interview, one of the pupils stated that "There are too many words that I don't understand", followed by another pupil saying, "I prefer playing on games than reading". Pupils with less interest in reading activities are found unable to recognize the words which retard reading and cause difficulty in comprehension of the text [25]. After the implementation step, the number of pupils who like reading stories has increased to $84 \%$. Also, after the use of Seesaw, the number of pupils who think reading is difficult has decreased to $52 \%$. This indicates that reading activities carried out by teachers in school could cultivate pupils' reading interest. This finding is also coherent with the findings of the Ontario Government [26] which concluded that learning to read must be taught in school in order to equip pupils to achieve a more advantage academic success.

On the other hand, $68 \%$ of the pupils responded that they prefer watching TV than reading books. Loan [27] commented that new technology like television, computer and cell phone has posed a threat to reading habits. In the pre-activity interview, one of the pupils commented, "I only like watching dramas on TV"; while the other one stated, "Watching Youtubers' videos is more fun than reading books." While after the implementation of Seesaw, the percentage of pupils who prefer reading books than watching TV has increased from $30 \%$ to $34 \%$. One pupil commented during the post-activity interview, "I did not know that reading can be interesting," while the other pupils said, "Now I think reading is much more meaningful than watching Youtube or TV programmes." The researchers suggested that the integration of technology in arousing pupils' reading interest has shown positive effect when the compatible online application is employed. This finding reflects the study by Biancarosa \& Griffiths [28], who suggested that technology can be conceptualized as affording tools that teachers can deploy in their quest to create young readers.

One of the findings from Table 2 shown that pupils find themselves are more pleased to go to the library after using Seesaw. In light of the Nilam reading programme which aimed to inculcate the reading habit among school pupils launched by the Ministry of Education in 1999 [32], the pupils are arranged to go into the library once a week to read under the guidance of a teacher. Before the Seesaw activity, only $52 \%$ of the pupils responded that they like going to the library. During the pre-implementation interview, one of the pupils said, "I dislike it when I am forced to read" while another pupil stated, "I always wish I can complete my school work during this period instead of reading." In this case, the reason for reading is external motivation [33]. Meanwhile, in the post-activity questionnaire, researchers found that an increment of $27 \%$ was shown on the same item. More pupils started to find pleasure in reading after the use of Seesaw. During the post-activity interview, pupil A commented, "I started to look forward to going to the library on this day," while pupil B said, "I do not feel odd anymore during this period in the library. It is because I find reading more interesting than before." On the other hand, pupil C also responded, "I now borrow books from the library and look forward to share my readings in Seesaw." These findings reflected that pupils start to spend more time reading when they are provided with a platform to boost their intrinsic motivation. 
This has shown that intrinsically motivated pupils tend to spend more time reading than those who have low intrinsic motivation for reading [34].

Next, only $56 \%$ of the pupils responded that they have a lot of books to read at home. While in the post-activity survey, an increment of 5\% was shown. Although the raise of percentage here does not guarantee a significant difference in interest gain in this study, the researchers suggested that the number of books at home does make an influence on raising the interest of reading as children need a conducive reading environment. This is in line with Bano, et al. [29], who supported that parents play a pivotal role in developing children's reading skills by providing a better reading environment at home. In the post-activity interview, pupil A was seen excited and commented, "We feel reading is fun now and so we ask our parents to buy more books to read at home" while pupil B stated, "I asked my mom to make a little reading corner for me so that I can spend more time reading there." As concluded by MacAulay [35], the physical environment does make an influence on students' behaviour and attitudes in learning. In this case, a conducive reading environment at home is essential to inculcate reading interest in pupils.

Apart from that, $64 \%$ of the pupils like reading with friends; $89 \%$ stated that they like to read with their parents or teacher while only $44 \%$ like reading alone. As mentioned by one of the respondents, "I am interested when I can discuss what I have read with my friends," and the other one stated, "I am happy to have my dad to read beside me". These findings showed that pupils find it more interesting and motivated to read when there are reading companions. The findings are also supported by Cremin, et al. [30] who commented that reading pleasure in children is strongly influenced by relationships between children, teachers, families and communities. After the activity is carried out, the percentage of pupils who like reading with friends has increased from $64 \%$ to $79 \%$ while $91 \%$ prefer reading companions after using Seesaw. Since this application is a tool that promotes collaboration and communication skills among users, children do find having reading companions makes reading more fun. This is also shown in one of the post-activity interviews where a pupil stated, "I wish I can read with friends and teachers every day" and the other one stated, "I look forward to reading activity in the class now." The findings are also coherent with Bano, et al.'s [29] findings which concluded that shared reading activities contribute delightful reading experience and fluency reading with expressions in children.

\section{Conclusions}

This paper discussed about the effect of Seesaw (an application tool) on increasing the interest of pupils in reading. The findings which are obtained through interviews and surveys conducted in this study have clearly shown that the use of Seesaw is indeed helpful in arousing the interest of pupils in reading. Besides, this tool is indeed beneficial to educators who are facing the same issues worldwide where pupils responded that they are showing more interest in learning after Seesaw is employed. This study also showed how reading activities could enhance pupils' reading experience and enabled them to more effective communication and meaningful learning.

This research highly encourages all key stakeholders to implement strategies and employ technology resources that will empower pupils in becoming successful learners as reading is indispensable and a valuable asset to any child who desires to explore the universe and to be knowledgeable [25]. For instance, to create a conducive environment to facilitate pupils in reading books (e.g. reading corners around the school, programs in collaboration with public libraries) and encourage parents to establish a share-reading relationship with their children at home. In doing so, pupils could be given alternative ways to foster the love for reading and contributing to higher academic achievement in return.

\section{Acknowledgments}

This research was supported by the grant from the Faculty of Education, Universiti Kebangsaan Malaysia GG-2018-001 and GG-2019-009.

\section{REFERENCES}

[1] PIRLS (2018). Progress in International Reading Literacy Study. National Center for Education Statistics, Institute of Education Sciences, PIRLS, USA. Online available from: https://nces.ed.gov/surveys/pirls/pdf/PIRLS_2018 brochur e.pdf

[2] Shaidatul, A. A. K. \&Debbita, A. L. T. (2019). ESL reading activities on Facebook among Malaysian university students. Pertanika Journal of Social Sciences \& Humanities, 27(1), 101-122.

[3] Mohd, S. F. (2003). English language teaching in primary schools: Policy and implementation concerns, IPBA E-Journal, 1-14. Online available from: https://kajianberas askansekolah.files.wordpress.com/2008/04/article70.pdf

[4] Yunus, M.M., Nordin, N., Salehi, H., Embi, M. A. \&Salehi, Z. (2013a). The Use of Information and Communication Technology (ICT) in Teaching ESL Writing Skills. English Language Teaching, 6, 1-8. doi.org/10.5539/elt.v6n7p1

[5] Seesaw. (2019). Online available from: https://web.seesaw. me/

[6] Yunus, M.M., Nordin, N., Salehi, H., Sun, C. H. \&Embi, M. A. (2013b). Pros and cons of using ICT in teaching ESL reading and writing. International Education Studies, 6(7), 
119-130. https://doi.org/10.5539/ies.v6n7p119

[7] Nordin, N. M., Hamzah, M. I., Yunus, M. M., \&Embi, M. A. (2010). The mobile learning environment for the in-service school administrators. In Procedia - Social and Behavioral Sciences, 7, 671-679. https://doi.org/10.1016/j.sbspro.2010 .10 .091

[8] Melland, H. I., \&Volden, C. M. (1996). Teaching portfolios for faculty evaluation. Nurse Educator 21(2), 35-38. https:/ /doi.org/10.1097/00006223-199603000-00012

[9] Murray, J. E. (1994). Why teaching portfolios? Community College Review, 22(1), 33-43. https://doi.org/10.1177\%2F 009155219402200105

[10] Krapp, A. (1999). Interest, motivation and learning: An educational-psychological perspective. European Journal of Psychology of Education, 14, 23-40. 10.1007/BF03173109

[11] Dewey, J. 1913. Interest and Effort in Education. Boston: Houghton Mifflin Company.

[12] Lipstein, R. L., Renninger, K. A. (2007). Writing and Motivation. Amsterdam, Netherlands: Elsevier.

[13] Moser, G. P., \& Morrison, T. G. (1998). Increasing students' achievement and interest in reading. Reading Horizons, 38 (4). Online available from https://scholarworks.wmich.edu/ reading_horizons/vol38/iss4/1

[14] Coan, D.L. (2007). Review of research on the role of interest level in students' reading materials. How Hot Topics: High-interest reading supports comprehension and learning. Evan-Moor Corp. Online available from: www.evan-moor. com/high-interest

[15] OECD (2018). PISA for Development Reading Framework, in PISA for Development Assessment and Analytical Framework: Reading, Mathematics and Science, OECD Publishing, Paris. https://doi.org/10.1787/97892643052744-en

[16] Yunus, M.M. \& Chun, J.S. (2016). Teachers' perspective on the reading behaviour of primary ESL learners in SJKC Chung Hwa Semera Sawarak. ICECRS, 1(2016), 493-498. http://dx.doi.org/10.21070/picecrs.v1i1.518

[17] Halliday, M. A. K. (2013). An introduction to functional grammar, 3rd edn, (Revised by C.M.I.M. Matthiessen), New York: Routledge.

[18] Tahar, M. M., Toran, H., Mohd, M. H. \& Bari, S. (2010). Reading skills among year one students in Malaysia. Procedia- Social and Behavioural Sciences, 9, 378-383. https://doi.org/10.1016/j.sbspro.2010.12.168

[19] Soureshjani, K. H. \&Etemadi, N. (2012). Listening comprehension success among EFL preschool children using internet- based materials. Journal of Social Sciences and Humanities, 7(2), 1-9.

[20] Zaki, A. A. \&Yunus, M. M. (2015). Potential of Mobile Learning in Teaching of ESL Academic Writing. English Language Teaching. 8(6), 11-19. http://dx.doi.org/10.5539/ elt.v8n6p11

[21] Malaysia National Library (Perpustakaan Negara Malaysia). (2005). Reading Promotion Policy. Online available from: http://i-baca.pnm.my/dasaren.asp
[22] Ministry of Education Malaysia. (2013). Malaysia Education Blueprint 2013-2015 (Preschool to Post-Secondary Education). Kementerian Pendidikan Malaysia (Ministry of Education), Putrajaya.

[23] Battaglia, M. A. 2008. Nonprobability sampling. Encyclopedia of survey research methods. Thousand Oaks: SAGE Publications, Inc.

[24] Strickland, D. \& Riley-Ayers, S. (2006). Early literacy: Policy and practice in the preschool years. National Institute for Early Education Research (NIEER), 10, 1-11. Online available from: http://nieer.org/wp-content/uploads/2016/0 8/10.pdf

[25] Akubuilo, F., Okorie, E. U., Onwuka, G. \&Uloh-Bethels, A. C. (2015). Reading readiness deficiency in children: causes and ways of improvement. Journal of Education and Practice, 6(24), 38-43. https://www.researchgate.net/public ation/281460792

[26] Ontario Government (2003). Early Reading Strategy: The Report of the Expert Panel on Early Reading in Ontario. Online available from: http://www.edu.gov.on.ca/eng/docu ment/reports/reading/reading.pdf

[27] Loan, F. A. (2009). Impact of new technology on reading habits: A glimpse on the world literature, presented in National Seminar Role of School Libraries in Quality Education, New Dehli, 2009. New Dehli: NCERT.

[28] Biancarosa, G., \& Griffiths, G. (2012). Technology Tools to Support Reading in the Digital Age. The Future of Children, 22(2), 139-160. Online available from www.jstor.org/stabl $\mathrm{e} / 23317415$

[29] Bano, J., Jabeen, Z. \& Qutoshi, S. B. (2018). Perceptions of teachers about the role of parents in developing reading habits of children to improve their academic performance in schools. Journal of Education and Educational Development, 5(1), 42-59.

[30] Cremin, T., Mottram, M., Collins, F., Powell, S. and Safford, K. (2009). Teachers as Readers: Building Communities of Readers 2007-08 Executive Summary. The United Kingdom Literacy Association.

[31] Malaysian Curriculum Development Department. (2018). Year 3 English Standard-Based Curriculum and Assessment Document for SJK. Putrajaya: Ministry of Education.

[32] Rajaendram, R. (2017, April 16). New and improved Nilam. The Star Newspaper. Online available from: https:/www.t hestar.com.my/news/education/2017/04/16/new-and-impro ved-nilam

[33] Ryan, R. M., \& Connell, J. P. (1989). Perceived locus of causality and internalization: Examining reasons for acting in two domains. Journal of Personality and Social Psychology, 57, 749-761.

[34] Wigfield, A. \& Guthrie, J. T. (1997). Relations of children's motivation for reading to the amount and breadth of their reading. Journal of Educational Psychology, 89, 420-432.

[35] MacAulay, D. J. (1990). Classroom environment: A literature review. Educational Psychology, 10(3), 239-253. 